\title{
Prospect Evaluation of the Ore Cluster I of Qunli Iron Mine in Golmud, Qinghai Province, China
}

\author{
Ji Shangwen \\ Qinghai Second Institute of Nonferrous Geological Exploration, Xining, Qinghai, China
}

Keywords: Golmud city, Qinghai, Ore cluster i of qunli iron mine, Deposit characteristics, Genesis, Prospecting signs, Prospect evaluation

\begin{abstract}
The mining area is located in the western section of the Qitamantag--Dulan polymetallic metallogenic belt formed in the Variscan period, with cobalt, bismuth, copper, lead and zinc, and thus it is a favorable mineralization section. The main exposed stratum in the mining area is the lower rock group of the Jinshuikou Group formed in the lower proterozoic, and the main lithological combination is mixed petrified gneiss with marble and skarn. Skarn is the main ore-bearing lithology in the area. Through the drilling engineering control of the minutely investigated area (Ore Cluster I), 17 iron ore bodies are delineated, with a length of 200-1500m, an inclined extension of $100-400 \mathrm{~m}$, an ore body thickness of $1-10 \mathrm{~m}$, and a burial depth of $200-400 \mathrm{~m}$. Judging from the exploration results of this area, the deep ore body in the mining area is large in scale and good in the prospecting prospect.
\end{abstract}

\section{Introduction}

The regional tectonic structure is located in the central and western sections of the Qimantag-Dulan orogenic belt. The metallogenic belt belongs to the Qimantag-Dulan Hualixi iron, cobalt, bismuth, lead, zinc, copper and silver metallogenic belt. The area has experienced many complicated and strong tectonic movements, and the structural traces of different scales and mechanical properties are well developed. In particular, the northwest-westward compressive and torsional faults constitute the main structural framework in this region, which plays an important role in controlling the distribution of strata, magmatic rocks, metamorphism and mineral resources in various periods.

\section{Regional Geological Background}

\subsection{Stratum}

The exposed strata in the area include the lower rock group $\left(\mathrm{Pt}_{1} j n^{\mathrm{a}}\right)$ and upper rock group $\left(\mathrm{Pt}_{1} j n^{\mathrm{b}}\right)$ of the Lower Proterozoic Jinshuikou Group, Upper Ordovician Ironstone Das Carbonate Formation $\left(\mathrm{O}_{3} t s^{\mathrm{c}}\right)$, Upper Devonian Qigaisu Group of conglomerate $\left(\mathrm{D}_{3} q g^{\mathrm{a}}\right)$ and volcanic rock $\left(\mathrm{D}_{3} q g^{\mathrm{b}}\right)$, Upper Carboniferous Diaosu Formation $\left(\mathrm{C}_{2} d\right)$ and Permian $\left(\mathrm{P}_{1}\right)$, Upper Triassic $\left(\mathrm{T}_{3}\right)$, Neogene $(\mathrm{N})$ and Quaternary (Q).

\subsection{Construction}

Tectonic overview of the area: Northwest-westward structural traces constitute the main structure in the area. It includes folds, schisms, and compressive faults with a structural surface of northwest-west ward. And the faulted structure is dominant. Associated with these compressive structural planes are north-north-east tensile faults, north-east-east tensile torsional faults, and north-north-west compressive torsional faults.

\section{Geological Characteristics of Mining Area}

The $\mathrm{Pt}_{1} j n^{\mathrm{a}}$ is mainly exposed in the mining area. Its lithology is mixed petrified gneiss with a small amount of marble and skarn (SK). Due to the influence of multiple tectonic movements and 
multi-stage magmatic rock intrusion, folds and fault structures are developed, the horizon is not very stable, and the rocks are subject to varying degrees of alteration. According to their lithological assemblage characteristics and metamorphism, they are divided into three types: mixed petrified gneiss, silicified marble and skarn. In addition, most of the surrounding strata are granite and diorite, and the valley section is in the Quaternary.

\subsection{Stratum}

The $\mathrm{Pt}_{1} \mathrm{jn}^{\mathrm{a}}$ is mainly exposed in the mining area. Its lithology is mainly composed of mixed petrified gneiss (mg), silicified marble (Mb) and skarn (SK), and a small amount of metamorphic quartzite and hornstone are seen locally.

\subsection{Construction}

The area has a monoclinic structure with a tendency to be near north and a dip angle of $10^{\circ}$ to $60^{\circ}$. However, folds are developed, resulting in variable attitude of rocks. The fault structure is developed and consists of the north-south fault group and east-west fault group.

\subsection{Magmatic Rocks}

Magmatic activity is frequent in this area, and its composition, occurrence, lithofacies and interpenetration are intricate; the magmatic activity is mainly concentrated in the variscan period.

\subsection{Metamorphism and Wall Rock Alteration (Hydrothermal Alteration)}

There are mainly the following types of metamorphism in the area: regional metamorphism, dynamic metamorphism, contact metamorphism, mixed petrification and hydrothermal metamorphism. Due to the multi-stage superposition of the above metamorphisms, the rocks in the mining area present a high degree of alteration, extremely uneven alteration and disordered alteration zoning.

\section{Geological Characteristics of the Deposit}

\subsection{Distribution and Scale of Ore (Body) Groups}

\subsubsection{Distribution and Scale of Mining Groups}

The Ore Cluster I is distributed between the 8-21 line in the middle and west of the mining area (as shown in Figure 1). Only I-18 and I-19 iron ore bodies are exposed on the ground. Controlled by the surface trenching project, the surface elevation is between $4500 \mathrm{~m}$ and $4700 \mathrm{~m}$, and the rest are blind ore bodies. The occurrence of the ore body has been elevated to $4000-4760 \mathrm{~m}$, with a burial depth of $100 \mathrm{~m}-414 \mathrm{~m}$. Due to the ore body's sloping to the west and the flank angle of $10^{\circ}-20^{\circ}$, the burial depth in the east of the ore body is relatively shallow, while that in the west is large. The ore body group has a length of 1580 meters, a width of about 550 meters, and a maximum slope length of 410 meters. The ore body is produced in skarn or the contact part of skarn with gneiss and marble. It consists of 19 iron ore bodies, of which the 1-17 exploration line is systematically controlled by drilling engineering, and the 2-6 exploration line is controlled through a single hole. The ore bodies are distributed in a vein-like and lens-like parallel arrangement, tending to near the north, with an inclination angle of $20^{\circ}$ to $50^{\circ}$. Among them, I-1, I-3 and I-4 ore bodies are very large.

After engineering control and comprehensive analysis, the Ore Cluster I (I-1-I-5) and the Ore Cluster II (II-1-II-9) in the original general survey belong to the same mineralization zone. The latter is the eastward extension of the former, and the ore body has good continuity. 


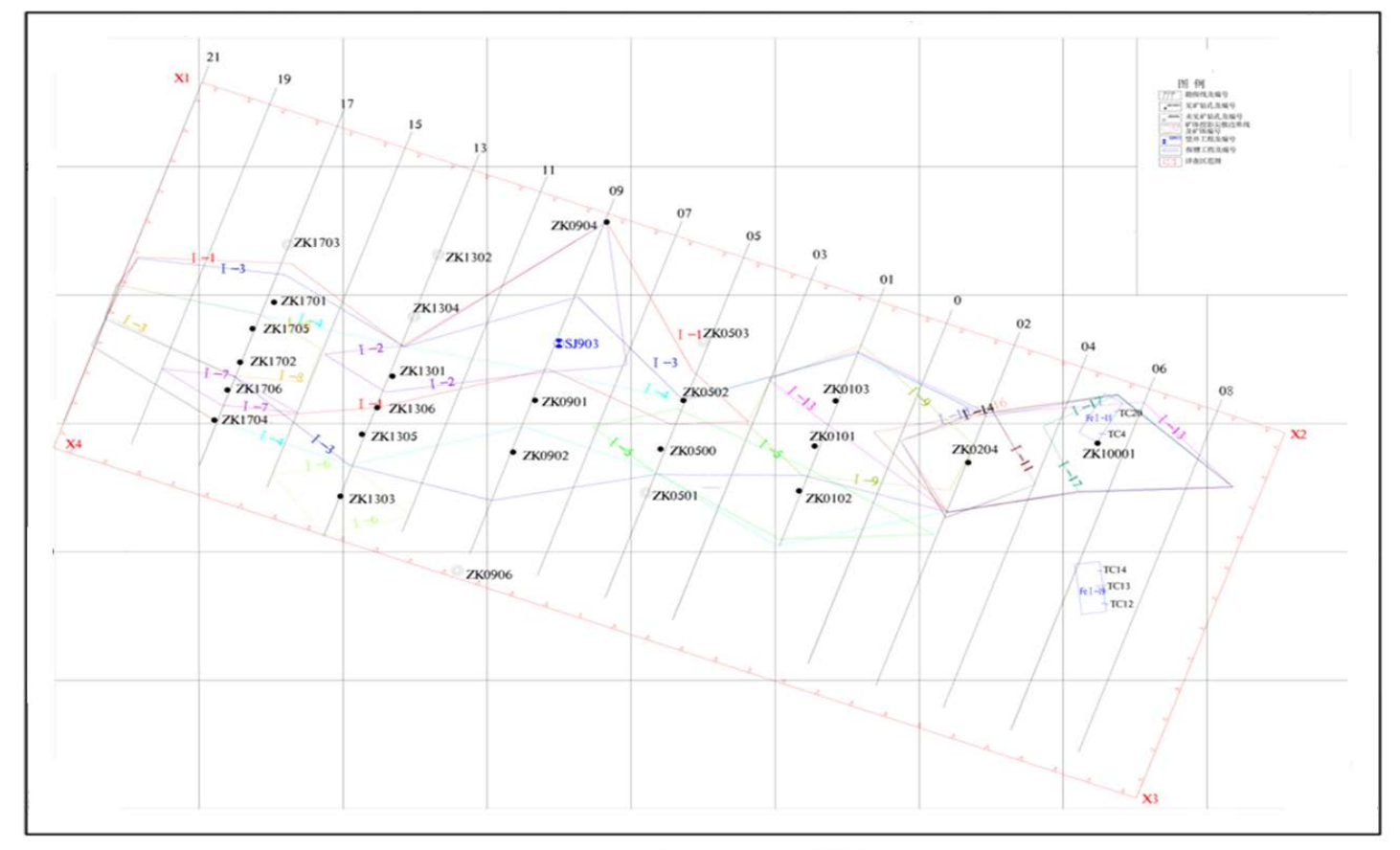

Fig.1 Horizontal Projection of Ore Cluster I of the Qunli Iron Mine in the Golmud City

\subsection{Main Ore Body Characteristics}

The I-1 ore body is a blind one, distributed between lines 21-3, with an ore body distribution elevation of $4180-4485 \mathrm{~m}$. The ore body has a length of $922 \mathrm{~m}$, an inclined depth of $110-176 \mathrm{~m}$, and a maximum depth of $375 \mathrm{~m}$. The general thickness of a single engineering ore body is $1.20-2.30 \mathrm{~m}$ and the maximum thickness is $5.44 \mathrm{~m}$. The ore body is vein-like and lens-like, and its appearance is $340^{\circ} \sim 10^{\circ} \angle 40^{\circ} \sim 44^{\circ}$. The ore is mainly magnetite, followed by pyrite magnetite ore; the average grade is $\mathrm{TFe} 36.46 \%$, and $\mathrm{mFe} 32.38 \%$.

The I-3 ore body is a blind ore body. It is the largest one in the mining area and is distributed between lines 21-8, with a distribution elevation of $4080 \mathrm{~m}-4495 \mathrm{~m}$. The ore body has a length of $1561 \mathrm{~m}$, with an inclined depth of $231-296 \mathrm{~m}$ and a maximum depth of $388 \mathrm{~m}$. The general thickness of a single engineering ore body is $0.86-8.66 \mathrm{~m}$, and the maximum thickness is $9.96 \mathrm{~m}$. The ore body is lens-like and vein-like, and its appearance is $340^{\circ} \sim 20^{\circ} \angle 18^{\circ} \sim 50^{\circ}$. The ore is mainly magnetite, followed by pyrite magnetite ore, and the average grade is TFe $40.08 \%$ and $\mathrm{mFe} 36.40 \%$.

The I-4 ore body is a blind ore body, distributed between the 21-2 line, with a distribution elevation of $4100 \mathrm{~m}-4450 \mathrm{~m}$. The ore body has a length of $1577 \mathrm{~m}$, with an inclined depth of $101-295 \mathrm{~m}$ and a maximum depth of $376 \mathrm{~m}$. The general thickness of a single engineering ore body is $0.65-12.10 \mathrm{~m}$, and the maximum thickness is $23.20 \mathrm{~m}$. The ore body is lens-like and vein-like, and its appearance is $350^{\circ} \sim 10^{\circ} \angle 29^{\circ} \sim 54^{\circ}$. The ore is mainly magnetite, followed by pyrite, magnetite and specularite, of which specularite is mainly distributed between the 9-2 exploration line in the upper east section of the ore body. The average grade of ore isTFe35.64\% and mFe26.78\%.

\section{Ore Quality}

\subsection{Material Composition}

The main useful ore minerals of iron ore are magnetite, followed by specularite and limonite. The Ore Cluster V in the east of the mining area contains copper minerals, mainly including chalcopyrite and its oxides copper blue, malachite, etc. The chemical compounds are pyrite and trace amount of galena, sphalerite, siderite, ferric silicate, etc.

There are many types of gangue minerals, mainly including diopside, epidote, chlorite, tremolite (actinolite), garnet, calcite, etc., followed by sericite and serpentine and other minerals. Table 1 shows the approximate content of various minerals in the iron ore. 
Table 1 Percent Content of Minerals in the Iron Ore

\begin{tabular}{|l|l|l|l|l|l|}
\hline Useful minerals & Content (\%) & Impurity minerals & Content (\%) & Gangue minerals & Content (\%) \\
\hline magnetite & 30 & Pyrite & 2 & Diopside & 21 \\
\hline Limonite & 2 & Galena & Trace amount & Tremolite (actinolite) & 12 \\
\hline Specularite & 1 & Sphalerite & Trace amount & Epidote (chlorite) & 10 \\
\hline$/$ & $/$ & $/$ & $/$ & Garnet & 5 \\
\hline$/$ & $/$ & $/$ & $/$ & Calcite & 7 \\
\hline$/$ & $/$ & $/$ & $/$ & Sericite (white) & 5 \\
\hline$/$ & $/$ & $/$ & $/$ & Serpentine & 5 \\
\hline Total & 33 & $/$ & 2 & $/$ & 65 \\
\hline
\end{tabular}

\subsection{Division of Metallogenic Epoch and Sequence of Mineral Generation}

Qunli Iron Deposit is a mixed petrified skarn-type iron deposit, and migmatization is the main factor of mineralization. From the perspective of its development process, the metallogenesis can be divided into two main stages, namely the early metaphase recrystallization stage and the mid-late hydrothermal metasomatism stage.

\section{Occurrence Rules of Ore Bodies, Genesis of Ore Deposits and Signs of Prospecting}

\subsection{Occurrence Law of Ore Body}

(1) The deposit is produced in the formation of mixed petrified gneiss mixed with marble and skarn in the lower rock group of the Jinshuikou Group formed in the lower proterozoic. The ore body is controlled by certain stratums (skarn), and its gneiss is generally subject to strong mixed petrification. Generally, the size of skarn determines the size of the ore body. If the size of the skarn is large, the scale of the ore body is large.

(2) Most of the ore bodies are lens-like and vein-like in parallel. The occurrence of the ore body is basically the same as the occurrence of its surrounding rocks. The overall tendency is near north, and the dip angle is $30^{\circ}-50^{\circ}$. Affected by the fold structure, the tendency of some parts is opposite, and the inclination becomes steeper or slower. The size of the ore body is medium, and its strike length is much larger than the inclined length, with a general ratio of 2 5:1.

(3) The composition of the ore is simple, and the grade changes relatively evenly. The useful minerals are mainly magnetite, followed by hematite (specularite), chalcopyrite, sphalerite, pyrite, etc. Gangue minerals are mainly diopside and tremolite (actinolite), followed by quartz, epidote, chlorite, garnet, calcite, feldspar, mica, etc. as well as trace amounts of apatite. The ores present the subhedral structure -- dominated by the granular structure. The ore structure is mainly block-shaped and disseminated, followed by strip-shaped and fine-veined structures. Most of the ores are lean ores, with a general iron content of $20-50 \%$; ore-rich bodies are locally distributed, with an iron content of up to $50-70 \%$.

(4) The surrounding rocks of the ore body is altered widely and seriously, mainly including epidotization (chloritization), tremolitization (actinolitization), potassic alteration, sericitization, pyritization, etc. Among them, the first three are closely related to mineralization and present obvious zoning phenomenon, generally from the inside to the outside: epidotization (chloritization) $\rightarrow$ tremolitization (cryolitization) $\rightarrow$ potassic alteration (silicification).

\subsection{Genesis of the Deposit}

According to the comprehensive analysis about the characteristics of the surrounding rocks of the ore body and the structural structure of the ore, the genesis of the deposit is very complicated, but the existing available data showed that it should belong to the skarn deposit related to mixed petrification. It basically has the following characteristics:

(1) The ore body was mainly produced in the $\mathrm{Pt}_{1} \mathrm{jn}^{\mathrm{a}}$ mixed petrified gneiss stratum. Rock mixed petrification is strong, and the iron content is generally high, which is the main source of ore-forming materials.

(2) The ore-bearing surrounding rocks of the deposit are mainly skarn. The skarn is lens-like and 
layer-like and distributed in parallel in the mixed petrified gneiss, which is basically consistent with the occurrence of gneiss. The outer zone where the skarn and gneiss is located in this deposit is in contact with potash-granite gneiss and it is a product of mixed petrification.

(3) There are silicified marbles in the skarn contact zone and nearby, indicating that skarn is a metamorphic product of marble. According to predecessors' temperature measurement for inclusions of ore minerals and gangue minerals in the mining area, the formation temperature of magnetite was between $500^{\circ} \mathrm{C}$ and $200^{\circ} \mathrm{C}$, and thus this deposit belongs to high-medium temperature hydrothermal metamorphic deposit.

(4) The magmatic rocks in the mining area are mainly granite and diorite formed in the variscan period, distributed on the north and south sides of the ore belt. They provided a heat source and ore-forming materials for the later transformation of the deposit, further enriched the magnetite to form ore-rich bodies, and also enriched copper and zinc-forming ore-forming materials to form copper and zinc ore bodies. Among them, the copper and zinc ore bodies are generally distributed in the deep or edge, that is, the section closer to the magmatic rock.

(5) The shape of the ore body is complicated, mainly lens-like and vein-like, followed by lentil-like, pod-like, and irregular-shaped. There is obvious boundary between the ore body and the surrounding rocks. The useful minerals in the ores are mainly magnetite, followed by chalcopyrite, sphalerite, pyrite, hematite, etc. The ores present various structure in shape, including xenomorphic granular structure, automorphic-hypidiomorphic granular structure, scale-like granular platy structure, cryptocrystalline structure, etc. The ore structure covers massive structure, disseminated structure, strip structure, fine vein structure, etc., with obvious hydrothermal account-filling characteristics.

\subsection{Prospecting Signs}

(1) Primary outcrop and oxidized outcrop of the ore body

In the M1, M4, M5, M6, M7, M8 magnetic anomalies, there are primary outcrops of iron ore bodies or oxidized outcrop left after weathering. These outcrops can directly indicate the location of ore (mineralized) bodies, and they can be regarded as the most important prospecting signs for surface prospecting.

(2) Magnetite field stones in slope deposits

The outcrop of the iron polymetallic ore body in the mining area is subject to strong oxidation and weathering and the surface outcrop of the ore body is weathered and eroded into slope deposits. This situation is relatively common in this mining area, and these field stones are also the important prospecting sign on the surface.

(3) Wall rock alteration near the ore body

In the process of mineralization, the surrounding rocks were subjected to hydrothermal fluids and produced strong alteration, which indirectly indicates the existence of ore. As mentioned earlier, skarn featured by chloritization, epidotization and tremolitization (cryolitization) are often developed near the contact zone between the rock mass and the surrounding rocks in the mining area, which is of great guiding significance for prospecting.

(4) Color change of surrounding rocks

The wall rocks near the mine are exposed on the surface, and the oxidation causes the iron-containing sulfide to change, and then deposit the iron oxide-containing mineral on the fracture zone and joint surface. When these minerals react with other secondary minerals, they show obvious red, brown and black. The color change of these surrounding rocks is helpful to roughly trace the ore-bearing skarn belt, and thus it is an indirect prospecting indicator.

(5) According to the characteristic that the magnetic anomaly corresponds well with the outcrop of the ore body, it indicates that the magnetic anomaly is an important sign for prospecting magnetite and its hidden ore body in the search area.

\section{Conclusion}

The mining area has circled 9 sites with 1/5000 high-precision magnetic measurement anomalies 
(numbered M0-M8) and 24 sites with 1/10,000 high-precision magnetic measurement anomalies (numbered C1-C24). Through the inspection and verification of the magnetic anomalies of M0 (C7), M1 (C8), M4 (C14), M5, M6 (C16), M8 (C20) and C5, magnetite ore bodies of different sizes have been found, which showed that magnetic anomalies are an important sign of prospecting in this area. However, most of the 1/10,000 magnetic anomalies currently delineated have not been checked and verified. C9, C15, C16, C17, C20 and other 1/10,000 high-precision magnetic anomalies are relatively large in scale and are distributed in the main mineralization belt in the central and eastern parts of the mining area. They indicate large potential prospecting space and it is expected to obtain further breakthroughs in further exploration.

42 iron ore bodies and 5 copper ore bodies have been delineated in the mining area, and they are divided into 5 ore body groups. The detected resource $(332+333+334)$ iron resource is $1247.28 \mathrm{wt}$, and the grade (TFe) is $37.42 \%$, mainly distributed in the Ore Cluster I, accounting for about $94.88 \%$ of the resource reserves in this region. The rest of the ore body groups are only given engineering control at the surface or in the shallow part. Their resource reserves are still unclear, and there is still much room for prospecting in the deep part.

\section{References}

[1] Zhao Yiming, Feng Chengyou, Li Daxin, et al. Metallogenic Setting and Mineralization-alteration Characteristics of Major Skarn Fe-polymetallic Deposits in the Qimantag area, western Qinghai Province [J]. Mineral Deposits, 2013(01): 1-19

[2] He Shuyue, Shu Shulan, Liu Yongle, et al. Summary of Effective Prospecting Methods in Qimantag area, Qinghai Province [J]. Mineral Deposits. 2013(01): 187-194

[3] Li Hongpu, Cao Yongliang, Guan Youguo, et al. Mineralization Characteristics of Iron-polymentallic Deposits in Sijiaoyang Area, East Kunlun Mountain, Qinghai Province [J]. Geological Bulletin of China, 2009(06): 787-793.

[4] Liu Yunhua, Mo Xuanxue, Zhang Xueting, et al. Geological Characteristics and Ore-controlling Conditions of Skarn Deposits in Yemaquan Area, East Kunlun [J]. Geology and Mineral Resources of South China, 2005(03): 18-23. 